\title{
The economics of sustainable residential building in Australia
}

\author{
Lefeng Liu ${ }^{1, a}$ Changjiang Liü ${ }^{2, b}$ \\ ${ }^{1}$ School of Property and Construction Management, RMIT University, Melbourne, Victoria, \\ Australia \\ ${ }^{2}$ College of Civil Engineering and Architecture of Weifang University, Weifang 261061,China \\ as3532740@student.rmit.edu.au, ${ }^{\mathrm{b}}$ BTLCJ@163.com
}

Keywords: sustainable building, willingness to pay, energy rating, valuation

\begin{abstract}
Sustainable buildings have been commonly considered as more expensive than traditional design building. Public has concerned about actual economic return of energy efficient building. This study tries to analyze economical return of sustainable residential building in Melbourne and what is rational decision of sustainable feature when occupants try to build a new house. This report result shows that some improvement of sustainable feature in building has positive impact on the value of building. This report is going to help investor and developer to make balance between the economical efficiency and energy efficiency of energy efficient building.
\end{abstract}

\section{Introduction}

Population growth and industrial development leads to dramatically increment of energy demand, and $80 \%$ of global energy consumption is based on fossil fuels. However, fossil fuels is limited and going to run out in next few decades. In addition, energy-related carbon dioxide (CO2) emissions are the majority of global greenhouse gas (GHG) emissions. This reflects the potential importance of reduction of energy consumption to save energy and lowering carbon dioxide emission in consumption.

The residential building sector together with other building sector in built environment has a significant contributor to the climate change and increment of climate demand. The $40 \%$ of the worldwide energy has been consumed by construction and operation of buildings. Residential building consume $13 \%$ of the total energy and the amount of energy is predicted to continue to increase due to increasing house size, the trend of smaller family sizes and project population growth [1].

The sustainable building, green building or energy-efficient building is critical to energy saving in Australia. In addition, sustainable building should not limit to save energy, is also can attributes of capital investment. In Australia, in order to reduce energy consumption by residential building, mandatory regulation of all new residential building of 6-Star equivalence has been the current minimum requirement and BCA section $\mathrm{J}$ also introduces how to achieve energy efficiency for all class 2 to class 9 buildings. The minimum building performance standards only focus on the thermal performance of the building for heating and cooling usage in Australia. However, equipment in the building such as lighting, ventilation, electronics still account for almost half of building energy consumption. Furthermore, occupant health and comfort, energy consumption from construction and disposal, renewable energy, passive design and other element are significant.

There are a lot of researches to focus on the reflecting phenomenon of sustainable building from willingness to pay, economical return and valuation. A significant gap in analysis remains a lack of research how occupants make decision to build a sustainable building.

\section{Literature review}

Occupants are willing to pay premium for energy-efficient building, but have lower willing to pay for building with environmental certification. Despite mandatory regulation toward thermal performance of building, the policy still has little impact on decision making of investor [2]. Lower 
willingness to pay building with environmental certificate maybe due to the fact that occupants are think building with environmental certificate has higher risk and lower value. In addition, the occupants maybe do not have enough energy efficient building knowledge to make decision.

Table 2 presents an overview of the total costs likely to be incurred in the construction of an average new home on Melbourne's urban fringe (including price of land purchase), with a base case 5 stars thermal performance scenario and the three improved thermal performance scenarios presented as alternative investment options. The mean capital cost of investment increases from \$AUS 1050 for '6 stars' investment, to \$AUS 4062 for ' 7 stars' investment to \$AUS 9204 for '8 stars' investment, as shown Table 2.

Higher thermal performance building means higher R-value material of façade, which has higher initial cost due to additional material cost, as shown in Table 2. The balance between the economic efficiency and energy efficiency of the building has significant impact on the decision-making. Net zero energy building can be achieved by higher thermal performance material and generating renewable energy in site, but high initial cost and technology limit it development. The results find that in Melbourne, Australia, there is a significant capital cost to achieve a ZEH (Zero Energy House) standard, presenting a potential barrier to new home owners [4]. However, moving to a through-life perspective shows that a ZEH is a least-cost scenario in terms of operational energy costs across the life of the house, with a payback period of 12-14 years [4]. This reduces even further when other elements such as resale value are included in the analysis. In addition, there are significant environmental benefits in avoiding greenhouse gas emissions [4].

Table 1Thermal performance of NatHERS Star rating [3]

\begin{tabular}{|c|c|c|}
\hline $\begin{array}{c}\text { NatHERSStar } \\
\text { rating }\end{array}$ & $\begin{array}{c}\text { Annual energy requirement in } \\
\text { Melbourne condition }\end{array}$ & $\begin{array}{c}\text { Improvement in efficiency } \\
\text { over mandatory requirement }\end{array}$ \\
\hline $5 \mathrm{star}$ & $182 \mathrm{MJ} / \mathrm{m} 2$ & 0 \\
\hline $6 \mathrm{star}$ & $138 \mathrm{MJ} / \mathrm{m} 2$ & $24 \%$ \\
\hline $7 \mathrm{star}$ & $100 \mathrm{MJ} / \mathrm{m} 2$ & $45 \%$ \\
\hline $8 \mathrm{star}$ & $64 \mathrm{MJ} / \mathrm{m} 2$ & $65 \%$ \\
\hline
\end{tabular}

Table 2 Indicative mortgage costs for new home builders for 4 mortgage scenarios[3].

\begin{tabular}{|c|c|c|c|c|c|}
\hline Scenario & $\begin{array}{c}\text { Total } \\
\text { upfront cost }\end{array}$ & $\begin{array}{c}\text { Borrowed } \\
(90 \%)\end{array}$ & $\begin{array}{c}\text { Monthly } \\
\text { repayments (7.25\%) }\end{array}$ & $\begin{array}{c}\text { Total 25 year } \\
\text { mortgage cost }\end{array}$ & $\begin{array}{c}\text { Total 25 year } \\
\text { interest }\end{array}$ \\
\hline 5 star & $\$ 393086$ & $\$ 354000$ & $\$ 2559$ & $\$ 767620$ & $\$ 413620$ \\
\hline 6 star & $\$ 394136$ & $\$ 355000$ & $\$ 2559$ & $\$ 769789$ & $\$ 414789$ \\
\hline 7 star & $\$ 397148$ & $\$ 358000$ & $\$ 2559$ & $\$ 776295$ & $\$ 418295$ \\
\hline 8 star & $\$ 402290$ & $\$ 362000$ & $\$ 2559$ & $\$ 784968$ & $\$ 422968$ \\
\hline
\end{tabular}

To understand energy-efficient, the content of energy rating system in world need to identify. After America develop a LEED green building rating system, other country have developed similar certification system, including the BREEAM rating system in the United Kingdom, Greenstar in Australia, BOMA BESt in Canada and Greenmark in Singapore. The minimum building performance standards in Australia were introduced in 2003, strengthen in 2006 and being further strengthened for 2011.As shown in Table 1, it is NatHERS Star rating standard in Australia.

A Analysis for 100 plans in Victory, Melbourne suggests that a 'seven' stars' thermal performance standard is cost-optimal for time-horizons of up to 25 years for a low energy price 
scenario, and that 'eight stars' thermal performance is optimal for a 40 years time-horizon at both high and low energy prices, and at 25 years for high energy price scenario analysis, under reference scenario conditions [5]. The author also indicated that percentage increase in house price due to a $1 \%$ increase in energy efficiency is between 0.2150 and 0.0211 based on Hedonic Pricing Method. The result means that on both environmental and economic aspect, higher level of mandatory energy performance and willingness to buy and build more energy-efficiency building should present[5].

Result shows that the discounting framework is the primary driver of difference in estimates about the cost of higher thermal efficiency in the residential sector [3]. In the case of residential thermal efficiency, a real discount rate of 3.5\% or below would serve to favour those investment options which maximize energy use reduction [3]. From LCCA, Life cycle costing of building contains several uncertainties duo to building has long life times. If the longer life cycle is considered, the inflation and discount rate will have more significant impact on accuracy.

Eichholtz et al.(2011)identified that energy-efficient building has premium price by $16 \%$, effective rent raised by $7 \%$ and green office provide $3 \%$ higher rents[6]. The author believes that energy-efficient building has important positive effect to building asset value. In addition, they find if the markert conditions are worse, premium of energy-efficient building tend to be higher than usual. Eichholtz et al. (2011) proved again their theory in more extend data and advanced economic techniques. Even during the economic downturn, energy-efficient office still has a high asset value[6].

According to Warren-Myers (2011)the role of values is missing, and their role as advisor to the different stakeholders of the market. As a result, decision made by occupiers, constructors, developers and investors is based on valuers opinion.

Valuers are not yet recognized the benefits of sustainability and reflecting this in their estimates of market value, as their knowledge and understanding of sustainability in property is limited[7].

The project developers start a new residential project want to make profit in short term, so they only build a house under building code and regulation. Without code and regulation, the energy-efficient building will be less than present level. However, the energy-efficient building has lower operating cost and higher value in market, there is a theoretical optimum where energy-efficient building can achieve highest economic return with suitable energy efficiency.

While year to year revisions of the building code have followed the incremental policy making model, there have been occasions, such as the introduction of 5 star and later 6 star standards, where the approach adopted has been the middle approach between incremental and rational policy making. A number of non-regulatory approaches targeting energy improvements in dwellings have also been developed over the past decade.

While the focus of this thesis is on minimum energy performance regulations, one significant policy development in Australia over the past decade has been the 2001 introduction of a Mandatory Renewable Energy Target (MRET, later to become RET), which set a goal of 20\% of total Australian energy generation from renewable energy sources by 2020 [8]. The RET advocated a two-pronged approach, which planned to use large scale as well as small scale domestic renewable energy installations to meet the renewable energy generation target in a transition towards a low carbon energy future. Similar programs and targets have been set internationally.

Behaviour affects residential energy use to the same extent as more efficient equipment and appliance. The policy encourage user to develop a strategy to improve efficiency in technology and behaviour and user get information/economic measures to make decisions weather to change behaviour or not [9]. The user can get information from written information in leaflets, advertisements, environmental awards and labelling of products, which can change or strengthen attitudes slowly and appear gradually over quite a long time period [9]. The economic instruments can have impact on user by taxing, discounts and reducing interest rate, which increasing awareness and making plans for energy saving and function as catalyst for changes in the future [9].

New residential building has much more potential to improve energy performance without comprise their requirement in Australia. However, location and cash flow rather than design or 
performance for users mainly contribute to their price. Financial benefits of sustainable technology are more complicated than a simple straight benefit analysis. Buildings including sustainable building are assets that are treated as having declining value as their systems and materials age and require replacement. Therefore, developer and investor need to carefully consider benefits of energy efficient building for example reduction in operational cost.

\section{Conclusion}

Development of sustainable residential building is critical to moderate the energy crisis and climate change. Where energy performance regulation is focusing on heating and cooling in Australia, housing market has failed to achieve a low emission housing stock.

In the literature review, the buyers have willingness to pay premium cost for energy efficient building but lower willingness to building with environmental certification is identified. The additional cost of energy efficient building compared with traditional design is introduced. Energy rating in Australia and its relationship between the prices of building is then focused. Energy efficient building in different market such as Japan, China, and USA is also introduced. Then, the process of LCCA and the hedonic pricing method is introduced for analysis the economical return of energy efficient residential building. Finally, Sustainability in valuation profession and some suggestions is identified in the paper.

Sustainable building has premium price in Australia residential building industry, and most people have less focus on Sustainable Declaration. From analysis, discount rate and inflation have significant impact on uncertainty of sustainable building due to building has long lifetime. The lack of sustainable knowledge in industry limits the development of sustainable building.

\section{Reference}

[1] Wang X, Chen D, Ren Z. Assessment of climate change impact on residential building heating and cooling energy requirement in Australia. Building and Environment. 2010 Jul 31;45(7):1663-82.

[2] Banfi S, Farsi M, Filippini M, Jakob M. Willingness to pay for energy-saving measures in residential buildings. Energy economics. 2008 Mar 31;30(2):503-16.

[3] Morrissey J, Meyrick B, Sivaraman D, Horne RE, Berry M. Cost-benefit assessment of energy efficiency investments: Accounting for future resources, savings and risks in the Australian residential sector. Energy Policy. 2013 Mar 31;54:148-59.

[4] Moore T. Modelling the through-life costs and benefits of detached zero (net) energy housing in Melbourne, Australia. Energy and Buildings. 2014 Feb 28;70:463-71.

[5]Morrissey J, Horne RE. Life cycle cost implications of energy efficiency measures in new residential buildings. Energy and Buildings. 2011 Apr 30;43(4):915-24.

[6]Warren-Myers G. Sustainability-The Crucial Challenge for the Valuation Profession. Pacific Rim Property Research Journal. 2011 Jan 1;17(4):491-510.

[7]Eichholtz P, Kok N, Quigley JM. Doing well by doing good? Green office buildings. The American Economic Review. 2010 Dec 1;100(5):2492-509.

[8] Sivaraman D, Horne RE. Regulatory potential for increasing small scale grid connected photovoltaic (PV) deployment in Australia. Energy Policy. 2011 Feb 28;39(2):586-95.

[9]Kahn EB, Ramsey LT, Brownson RC, Heath GW, Howze EH, Powell KE, Stone EJ, Rajab MW, Corso P. The effectiveness of interventions to increase physical activity: A systematic review1, 2 1The names and affiliations of the Task Force members are listed in the front of this supplement and at www. thecommunityguide. org. 2Address correspondence and reprint requests to: Peter A. 
Briss, MD, Community Guide Branch, Centers for Disease Control and Prevention, 4770 Buford Highway, MS-K73, Atlanta, GA 30341. E-mail: PBriss@ cdc. gov. American journal of preventive medicine. 2002 May 31;22(4):73-107. 